\title{
Pore-volume alteration measurements to evaluate scale formation during solid-fluid interactions
}

\author{
Prathap Moola ${ }^{1,2, *}$, Bergur Sigfússon ${ }^{2}$ And Andri Stefánsson ${ }^{1}$ \\ 1 Institute of Earth Sciences, University of Iceland, Sturlugata 7, 101 Reykjavík, Iceland \\ 2 Reykjavík Energy, Baejarhálsi 1, 110 Reykjavík, Iceland
}

[Received 4 May 2014; Accepted 20 October 2014; Associate Editor: T. Stawski]

\section{ABSTRACT}

Pore-volume changes in porous media during water-rock interaction can be studied using hydrological tracers. The tracers used here were amino $\mathrm{G}$ acid, napthionic acid and fluorescein at $\mathrm{pH} 3$ and 6.5 in contact with basaltic glass, quartz and rhyolite. The experimental setup mimicked that of a hydrological tracer test where a fixed volume of tracer was injected into a flow-through column and the breakthrough curve monitored. The measured breakthrough tracer curves were compared to theoretical 1-D reactive transport simulations calculated using the PHREEQC program. In some cases the tracers were observed to behave ideally, whereas in others they clearly reacted with the solid surfaces. This implies that some common hydrological tracers used in groundwater hydrology may not be suitable under all conditions as they may react with the surrounding rocks in the groundwater system.

KEYWORDs: hydrological tracers, pore-volume alteration, scale, water-rock interaction.

\section{Introduction}

SCALING in geothermal systems may be a major problem during their exploitation. In the Hellisheidi geothermal field, for example, scales are formed on the surface of pipelines and in feed zones of production and injection wells (Sigfusson and Gunnarsson, 2011). One method employed to study the formation of scales is to perform column experiments in the laboratory to observe any change in tracer breakthrough curves with time, either in their shape or magnitude. The breakthrough time of the tracer indicates a porevolume change proportional to scale formation. For an inert tracer, a change in the breakthrough curve shape can indicate scale formation and blockage of pores and subsequent dual porosity flow. If the tracer is not completely inert, however, the same curve-shape change may be a result of chemical reactions of sorption/desorption

* E-mail: snp3@hi.is

DOI: 10.1180/minmag.2014.078.6.06 of the tracer instead of precipitation of secondary minerals. Selection of an appropriate tracer for the system under study is of significant importance, therefore, for reliable interpretation of the processes occurring in the system.

\section{Tracers to study pore volume}

Tracer tests are one of the common methods used to study groundwater flow and subsurface groundwater system properties such as porosity and dispersivity (Ptak et al., 2004). Tracer tests can be performed both in the field and in the laboratory by measuring the concentration of species that are already present or are introduced deliberately into the system. Fluorescent dyes are often used for this purpose. In the present study the geochemical behaviour of three fluorescent dyes was studied

This paper is published as part of a special issue in Mineralogical Magazine, Vol. 78(6), 2014 entitled 'Mineral-fluid interactions: scaling, surface reactivity and natural systems'. 
PRATHAP MOOLA ET AL.

TABle 1. Properties of fluorescent dyes used.

\begin{tabular}{|c|c|c|c|c|c|c|}
\hline Tracer & $\begin{array}{c}\text { C.I. } \\
\text { name }\end{array}$ & CAS number & $\begin{array}{c}\text { Chemical } \\
\text { formula }\end{array}$ & Hue & $\begin{array}{l}\text { Mol. wt. } \\
\text { (g/mol) }\end{array}$ & $\begin{array}{c}\text { Maximum } \\
\text { absorption } \\
\quad(\mathrm{nm})\end{array}$ \\
\hline Fluorescein sodium & Acid yellow 73 & $518-47-8$ & $\mathrm{C}_{20} \mathrm{H}_{10} \mathrm{Na}_{2} \mathrm{O}_{5}$ & Dark red & 376.27 & 440 \\
\hline Amino $G$ acid & - & $303137-06-6$ & $\mathrm{C}_{10} \mathrm{H}_{8} \mathrm{KNO}_{6} \mathrm{~S}_{2} \cdot \mathrm{H}_{2} \mathrm{O}$ & Beige & 359.42 & 250 \\
\hline Napthionic acid & - & $84-86-6$ & $\mathrm{C}_{10} \mathrm{H}_{9} \mathrm{NO}_{3} \mathrm{~S}$ & $\begin{array}{l}\text { Light } \\
\text { grey }\end{array}$ & 223.25 & 320 \\
\hline
\end{tabular}

including amino $G$ acid, fluorescein and napthionic acid (Table 1). The selection of the tracer is based on chemical behaviour, detection limit, injection rate and $\mathrm{pH}$ (Axelsson et al., 2005). The tracer should exhibit low toxicity, show relatively conservative behaviour and be inexpensive to analyse. No ideal tracer exists that can fulfill all experimental requirements (Malcolm, 2002).

\section{Materials and methods}

The solid materials used in the laboratory experiments were a well-defined basaltic glass, from Stapafell, Iceland (Gislason and Oelkers, 2003), rhyolite from the 1875 eruption of Askja Volcano, Iceland and quartz, purchased from Sigma Aldrich (83340-1KG). All solid samples were ground in an agate mortar prior to dry sieving to obtain the desired size fraction of $45-125 \mu \mathrm{m}$. Subsequently the solids were cleaned in deionized (DI) water (resistivity $>18.2 \mathrm{Mohm}$ ) and gravitational settling, and cleaned thereafter for six cycles in an ultrasonic bath using DI water and one cycle in acetone to remove fine particles from the grain surfaces. By this method a homogenous coarse silt to very fine sand grainsize $(45-125 \mu \mathrm{m})$ was attained.

The three common hydrological tracers, amino $\mathrm{G}$ acid, fluorescein and napthionic acid, were purchased from Sigma Aldrich. The $\mathrm{pH}=3$ experimental solution was prepared from $\mathrm{HCl}$ acid and deionized water; the $\mathrm{pH}=6.5$ solution was prepared by dissolving suitable amounts of $\mathrm{Na}_{2} \mathrm{CO}_{3}$ and $\mathrm{NaHCO}_{3}$ salts in deionized water. These reagents were also purchased from Sigma Aldrich.

Solid rock material was dry packed inside the polytetrafluoroethylene column $(16 \mathrm{~cm}$ long, $1 \mathrm{~cm}$ thick wall and $1 \mathrm{~cm}$ inner diameter). All experiments were conducted at $25^{\circ} \mathrm{C}$. A background experimental solution ('Blank' in Fig. 1)

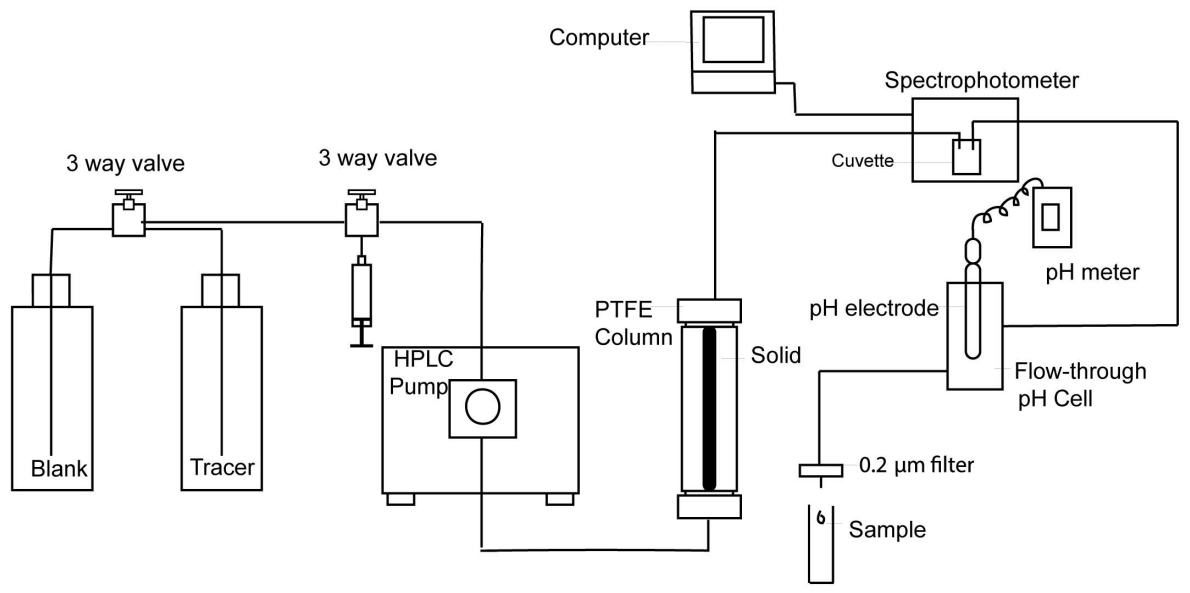

FIG. 1. Experimental setup. 

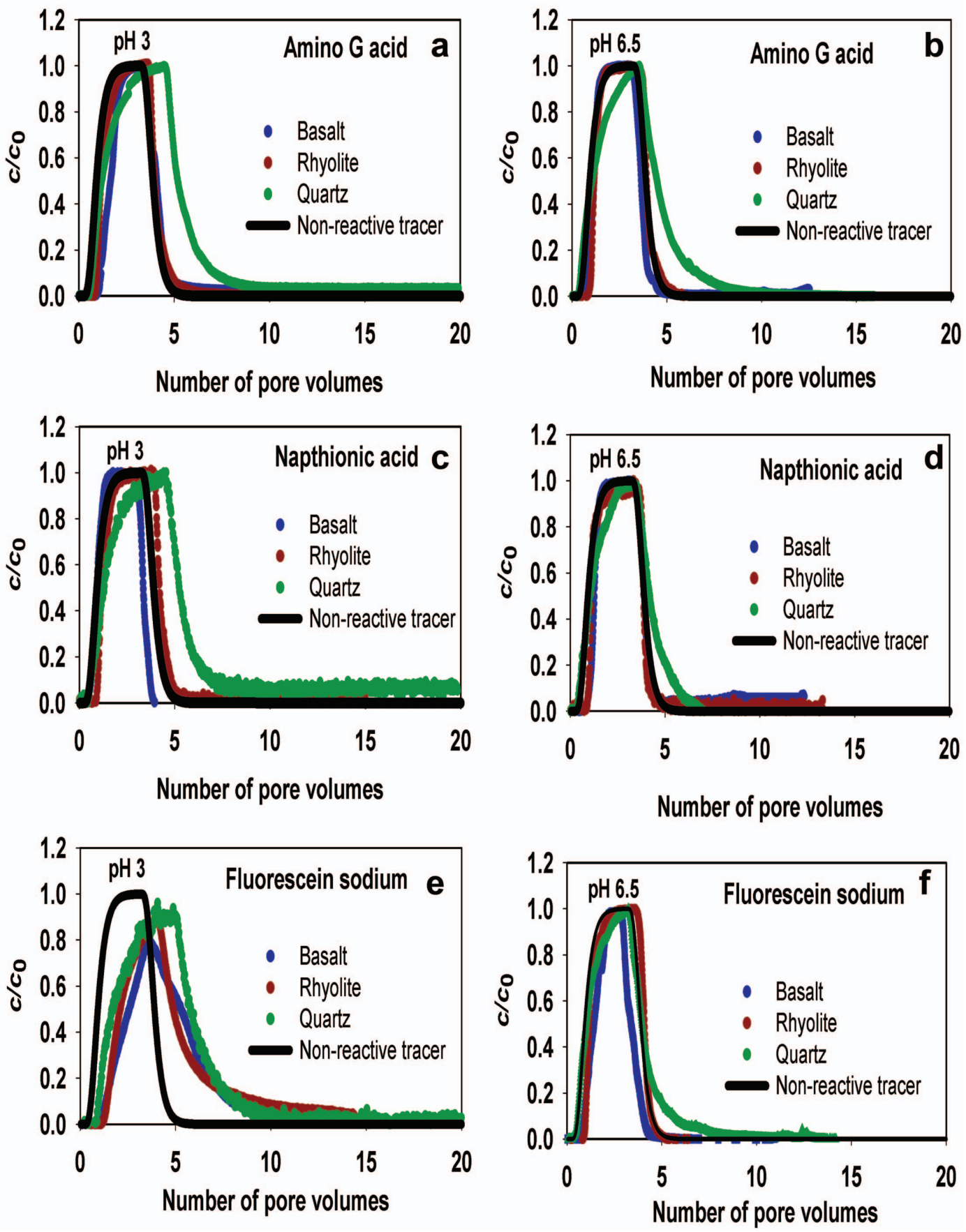

FIG. 2. Breakthrough curve of non-reactive $(d)$, reactive $(c, e, f)$ and partially reactive $(a, b)$ tracers. 
of $\mathrm{pH} 3$ or 6.5 was pumped using a HPLC pump at a steady flow rate of $1 \mathrm{ml} / \mathrm{min}$ until a stable baseline was obtained. After that the three-way valve was switched to allow the solution containing a known concentration of tracer (tracer in Fig. 1) to flow through the column at the same flow rate for $20 \mathrm{~min}$. Then the three-way valve was switched back to background experimental solution. The outlet solution passes through a cuvette first, for the spectrophotometric determination of the tracer, and in a flow-through $\mathrm{pH}$ cell afterwards, for $\mathrm{pH}$ measurement with a frequency of one reading per minute. Samples were collected continuously every $2 \mathrm{~min}$ to calculate the flow rate and thereby the reaction rate. The $\mathrm{pH}$ was recorded by a flow-through meter and was noted every minute.

The mass of tracer injected into the system was calculated by multiplying the measured inlet tracer concentration and flow rate $v s$. time. The recovery of tracers from the column experiments was estimated by the Qtracer2 program (Malcolm, 2002). The Qtracer program is used to study tracer breakthrough curves generated from data obtained while conducting tracer tests mainly in fractured rock aquifers and the results also aid solute-transport modelling.

\section{Results and discussion}

The results of flow-through column experiments show that both napthionic acid and amino $\mathrm{G}$ acid tracers (Fig. 2) follow similar trends, with the tracer concentration attaining the baseline value after $\sim 5$ pore volumes. These experimental results for the basaltic glass and rhyolite coincide with the modelled trend of a conservative tracer, whereas the results for quartz show a minor delay. In contrast, fluorescein tracer does not follow the trend and the delay may be due to adsorption of the tracer inside the column.

Three types of tracer trends were observed through comparison of breakthrough curves (Fig. 2) with the simulated behaviour of a conservative tracer, i.e. chloride ion, obtained by 1-D reactive transport using PHREEQC (Appelo and Postma, 1999):

(1) Always non-reactive, the mass of tracer injected is recovered for all the three solid materials studied (e.g. napthionic acid $\mathrm{pH}$ 6.5; Fig. $2 d$ ).

(2) Reactive, recovery depending on the material, as in the case of fluorescein at $\mathrm{pH} 3$ (Fig. 2e), with a recovery for basaltic glass which is less than for rhyolite and quartz. Irrespective of the material, at $\mathrm{pH} 3$, fluorescein has $<90 \%$ recovery and does not follow the ideal breakthrough curve pattern with the maximum peak delayed and tailing. The reactive behaviour of the tracer could be the effect of adsorption and desorption on the surface. Similar trends, i.e. the effect of adsorption and desorption were observed for napthionic acid at $\mathrm{pH} 3$ (Fig. 2c).

(3) Either non-reactive or reactive as in the case of amino $\mathrm{G}$ acid at $\mathrm{pH} 3$ and 6.5 (Fig. $2 a, b$ ). Breakthrough curves for both basalt and rhyolite are close to that of an inert theoretical tracer with $100 \%$ recovery whereas the breakthrough curve for quartz shows $97 \%$ recovery and considerable tailing.

The behaviour of fluorescein was closer to that expected for an inert tracer at $\mathrm{pH} 6.5$ (Fig. 2f) than at $\mathrm{pH} 3$ (Fig. 2e) indicating the suitability of the tracer for tests at near-neutral conditions and its unsuitability in acid conditions.

The results of tracer tests that were conducted at a production well in Laugaland, Iceland with fluorescein show that this tracer exhibits reactive behaviour, under field conditions, similar to that observed in the column experiments of this study. Both delay in recovering the injected mass and very low recovery were observed (Axelsson et al., 2001). A very similar trend but with less recovery was found for the tracer tests that were conducted for a carbon dioxide sequestration experiment at Hellisheidi, Iceland using fluorescein tracer (Rezvani Khalilabad, 2008).

\section{Conclusions}

The laboratory column experiments carried out during the present study suggest that not all tested tracers exhibited non-reactive or ideal behaviour. Tracers were classified into three types: (1) always non-reactive; (2) reactive, and (3) either non-reactive or reactive depending on the solid material. Based on the recovery percentage and the comparison with the ideally conservative tracer, not all fluorescent dyes are suitable for studying the pore-volume changes in fluid-rock interaction experiments, which represent the ultimate aim of this research. The next step will be to simulate 1-D reactive transport for different tracers under more diverse conditions. The least reactive tracers from this preparatory study will be used to follow pore-volume changes in future experiments. 


\section{Acknowledgements}

This research was made possible by a Marie Curie grant from the European Commission in the framework of the MINSC ITN (Initial Training Research network), Project number 290040. The authors thank their many colleagues for help in this research, especially Jan Prikryl and Snorri Gudbrandsson at the University of Iceland, and Einar Gunnlaugsson and Ingvi Gunnarsson at Reykjavik Energy.

\section{References}

Appelo, C.A.J. and Postma, D. (1999) A consistent model for surface complexation on birnessite $\left(\delta-\mathrm{MnO}_{2}\right)$ and its application to a column experiment. Geochimica et Cosmochimica Acta, 63, 3039-3048.

Axelsson, G., Flovenz, O.G., Hauksdottir, S., Hjartarson, A. and Liu, J. (2001) Analysis of tracer test data, and injection-induced cooling, in the Laugaland geothermal field, N. Iceland. Geothermics, 30, 697-725.

Axelsson, G., Björnsson, G. and Montalvo, F. (2005)
Quantitative interpretation of tracer test data. World Geothermal Congress, Antalya, Turkey, pp. 24-29.

Gislason, S.R. and Oelkers, E. (2003) Mechanism, rates, and consequences of basaltic glass dissolution, II. An experimental study of the dissolution rates of basaltic glass as a function of $\mathrm{pH}$ and temperature. Geochimica et Cosmochimica Acta, 67, 3817-3832.

Malcolm, S.F (2002) The QTRACER2 Program for Tracer-Breakthrough Curve Analysis for Tracer Tests in Karstic Aquifers and Other Hydrologic Systems. EPA/600/R-02/001, p.11.

Ptak, T., Piepenbrink, M. and Martac, E. (2004) Tracer tests for the investigation of heterogeneous porous media and stochastic modelling of flow and transport - a review of some recent developments. Journal of Hydrology, 294, 122-163.

Rezvani Khalilabad, M. (2008) Characterization of the Hellisheidi-Threngsli $\mathrm{CO}_{2}$ sequestration Target Aquifer by Tracer Testing. Oddi, Reykjavik, Iceland. Master thesis, University of Iceland

Sigfusson, B. and Gunnarsson, I. (2011) Scaling prevention experiments in the Hellisheidi power plant, Iceland. Thirty-Sixth Workshop on Geothermal Reservoir Engineering, Stanford University, Stanford, California, SGP-TR-191. 